with many short, darker brown strigæ ; a dark brown tinge along dorsal line, the edges of wing cases and the points over the eyes. Between the thoracic and abdominal prominences, along the thorax laterally and back of the eyes are large yellowish-white metallic patches. Length, $\mathbf{2 3} \mathbf{m m}$.; width through wing-cases, $9 \mathrm{~mm}$.

Food-plants.-Species of oak (Quercus.)

\title{
ON CATOCALA FLEBILIS AND C. FRATERCULA.
}

BY A. R. GROTE, A. M.

In describing $C$. retecta and $C$. flebilis, it appears, from Mr. Hulst's statements, that I included certain dark shaded specimens, one or more of retecta, under flebilis. Mr. Hulst says :- "The typical specimens in Phila. cover both species." This may be true, as also that Mr. Strecker figures a dark shaded retecta as flebilis. I have not his work. But there is no doubt in my mind as to what was flebilis, and there is no excuse for Mr. Hulst's renaming my species as luctuosa. Considerable material of flebilis from various sources was named by me at the time and notably for Mr. Angus, and there is no doubt as to my original intention. I noticed from the first the brown shade on primaries of flebilis, and imagined it might be accidental on my specimens and due to cyanide, as then we were hearing for the first time of the action of that poison on colour.

Without the slightest reason, Mr. Hulst quotes fratercula as the species intended by Guenee as micronympha. Under sancta, Mr. Hulst writes :- "Mr. A. G. Butler writes me this latter is connubialis, Guen., but the description does not fit, and it was described from a drawing, and so the name does not in any case hold." Without agreeing, this statement seems to me to apply to the use of micronympha for fratercula, and, in any event, I hope entomologists will not adopt these changes. Mr. Hulst has adopted, without acknowledgment, most of my corrections of his former work on this genus, as to the value of certain species and varieties, and one or two points of difference may be ultimately decided in his favour. I am, however, of a very strong mind upon two points, namely, that C. residua (photographed by me in Bull. Buff. Soc. Nat. Sci.) is a perfectly distinct species, and that the same is true of Meskei. Secondly, that my genus Euparthenos (Ann. Lyc.) is a valid genus, and the species E. nubilis structurally different from Catocala. I reserve until another occasion a criticism of Mr. Hulst's paper. 